\title{
Influence of tank volume on vitellogenesis and spawning performances in sea bass Dicentrarchus labrax $L$.
}

\author{
Vincent Buchet $^{1,{ }^{*}}$, Elodie Coquard $^{1}$, Armelle Sévère $^{1}$ \& Hervé Barone ${ }^{1}$ \\ ${ }^{1}$ UMR 1067 Nutrition Aquaculture and Genomics of Fish, Ifremer, Plouzané, France \\ *: Corresponding author : V. Buchet, UMR 1067, Nutrition Aquaculture and Genomics of Fish, Ifremer, BP 70, \\ 29280 Plouzané, France. email address : Vincent.Buchet@ifremer.fr
}

\begin{abstract}
:
Sea bass, Dicentrarchus labrax (mean weight: $748 \pm 13 \mathrm{~g}$ ), were maintained before and during vitellogenesis in $1,3,8,16$ and $32 \mathrm{~m} 3$ tanks, and then they were transferred to $2 \mathrm{~m} 3$ tanks, for the spawning season. During the first 2 months of the experiment, the growth rates were significantly lower in smaller tanks (1 m3). In August, the oocyte diameters were significantly lower in smaller tanks $(1,3$ and $8 \mathrm{~m} 3)$ than in larger $(16-32 \mathrm{~m} 3)$ tanks. At the end of the experiment, the fish mean weight in the $1 \mathrm{~m} 3$ tanks was significantly lower than in the $3 \mathrm{~m} 3$ tanks, but oocyte diameters and plasma oestradiol concentrations were not significantly different between the volumes. This shows a longer acclimation requirement in smaller volume rearing. Although all the females had not spawned, one spawn at least was collected in each volume. The variation in conditioning volume has not blocked the spawning process. The qualitative and quantitative characteristics of spawns were not significantly different between volumes. The conditioning volume of $3 \mathrm{~m} 3$ seems to be a minimal volume required to obtain good reproduction of sea bass.
\end{abstract}

Keywords: Sea bass, Reproduction, Vitellogenesis, Aquaculture, Volume 
30 For temperate species fish such as the European sea bass, photoperiod and temperature are

31 the main environmental factors controlling the process of sexual maturation and reproduction 32 (Bromage 1995; Carrillo, Zanuy, Prat, Cerda, Ramos, Mananos \& Bromage 1995; Mananos, 33 Zanuy \& Carrillo 1997; Bromage, Porter \& Randall 2001; Rodriguez, Begtashi, Zanuy, Shaw \& 34 Carrillo 2001). The salinity, the oxygenation and the water quality play a minor role. Other 35 factors related to the culture conditions, such as tank hydraulics, rearing density or farming manipulations, can also influence the reproduction of numerous species: common carp (Sehgal \& Toor 1995), tilapia (Siddiqui, Al-harbi \& Hafedh 1997; Ridha \& Cruz 1999), Pagrus auratus (Cleary, Pankhurst \& Battaglene 2000; Schreck, Contreras-sanchez \& Fitzpatrick 2001). They can have a limiting or an activating role in the reproduction and they can influence the spawn quality (Bromage 1995). Although investment in rearing structures is an important part of the budget of a hatchery project, very few studies have been carried out on the influence of tankrearing volume on spawning performance. Nevertheless, it has been reported that tank volume may influence the welfare of the fish. Hence, mortality associated with repeated handlings is lower for turbot (Scophtalmus maximus L.) held in small tank volumes $\left(2 \mathrm{~m}^{3}\right)$ than those maintained in larger ones $\left(16 \mathrm{~m}^{3}\right)$ (Mugnier, Fostier, Guezou, Gaignon \& Quemener, 1998). Similarly, a temporary reduction ( 2 weeks) in the tank volume during the final stages of gametogenesis influences negatively the quality of gametes produced by brown (Salmo trutta) and rainbow trout (Oncorhynchus mykiss) (Campbell, Pottinger \& Sumpter 1994). Fornies, Mananos, Carrillo, Rocha, Laureau, Mylonas, Zohar and Zanuy (2001) showed that the quality of the spawns of sea bass held individually in a $2 \mathrm{~m}^{3}$ tank is lower than that of fish held in $15 \mathrm{~m}^{3}$ tanks. However, in his study, the fish densities and sex ratios were different. Thus, it is difficult to differentiate the respective effects of density and volume on the quality of gametes and the survival rates of the progeny.

54 Finally, very few studies have focused on only the effect of tank rearing volume on reproductive performances. Okumura, Okamoto, Oomori and Nakazono (2002) showed that water height and pond volume could limit the emergence of reproductive behaviour preceding spawning of 
biomass, the production of eggs of Oreochromis niloticus per $\mathrm{m} 2$ is inversely proportional to the size of the reproduction ponds. The spawns of zebra fish (Danio rerio) maintained in volumes of 200 or $100 \mathrm{~mL}$ represent, respectively, $48 \%$ and $26 \%$ of the production obtained with breeders maintained in aquariums of $3.5 \mathrm{~L}$ (Goolish, Evans, Okutake \& Max 1998). The objective of this experiment was to estimate the influence of tank volume during gametogenesis on individual spawning performances of the European sea bass, firstly, by follow-up of the effects on the gonadic development and on the plasmatic E2 profiles and, secondly, by comparing these observations with the quantitative and qualitative characteristics of the individual spawns observed during the reproductive season. This would allow showing a correlation between the reduction in the tank volume and the decrease in the spawn performances and also determination of the minimum volume that blocks the reproduction. The present study was conducted on sea bass Dicentrarchus labrax that spawns spontaneously in captivity and due to its economic importance for European aquaculture.

\section{Materials and Methods}

73 Fish and rearing conditions

74 The European sea bass Dicentrarchus labrax L. used in this experiment were hatched at the Ecloserie Marine de Gravelines (France) and reared in our experimental facilities for 3 years. During six months preceding the experiment, fishes were maintained in 6 tanks of $3 \mathrm{~m}^{3}$ of volume. The experiment was divided into two phases: the first, "conditioning period", which was squared with the whole gametogenesis and the second, "spawning period", which starts at the end of vitellogenesis and covers the duration of the spawning period.

80 Sexually mature sea bass (mean weight: $748+/-13 \mathrm{~g}$ ) were randomly distributed in $1,3,8,16$ and $32 \mathrm{~m}^{3}$ tanks ( 3 tanks for $" 1 \mathrm{~m}^{3}$ condition" and 1 tank for the other conditions), at the density of 3 fishes per $\mathrm{m}^{3}$ and a sex ratio of 2 males: female during the conditioning period (from the end March to end December). Each tank of 1, 3, 8, 16 and $32 \mathrm{~m}^{3}$ contained 3, 9, 24, 48 and 96 fishes respectively. Under-skin magnetic tags implanted in gill cover individually identified the fish. Breeders were maintained under natural photoperiod and water temperature of the roadstead of Brest (latitude $4821^{\prime} \mathrm{N}$ ). At the end of the first period, the females were considered 
87 ripe when mean diameter of oocyte reached $800-900 \mu \mathrm{m}$. The males were selected based on their ripeness characters (spontaneous sperm release). Each selected female was transferred into spawning tank for an individual monitoring at same sex ratio than previously (2 males: female). 3 spawning tanks were brought into second phase for each conditioning volume (3

91 replicates), according to the method used by Suquet, Normant, Gaignon, Quéméner and Fauvel (2005). Egg collectors allowed us to collect both floating and sinking eggs from each spawning device. Spawns occurred spontaneously.

94 The conditioning $\left(1,3,8,16\right.$ and $\left.32 \mathrm{~m}^{3}\right)$ and spawning $\left(2 \mathrm{~m}^{3}\right)$ tanks were supplied with running seawater to a flow corresponding to $30 \%$ of the volume of each tank per hour. The oxygen level was maintained around $80 \%$ of the saturation. During the conditioning period, fish were fed "ad libitum", every day, with commercial feed (Neo Repro, Le Gouessant ${ }^{\circledR}$ - Lamballe - France, pellet diameter $9 \mathrm{~mm}$ ). During the spawning period, a small quantity of food was provided to avoid a weight loss and keep the tanks clean when the temperature exceeds $12^{\circ} \mathrm{C}$.

101 Studied parameters

102 Every month (from March to December), during the "conditioning period", all the fish of all 103 experimental units were caught and anesthetized with ethylene glycol monophenylether 104 (200ppm). Growth was estimated by individual weighing of all fish. From these, Specific growth 105 rate $\left(S G R, \% d a y^{-1}\right)$ was calculated as: $100 \times\left(\ln w_{f}-w_{i}\right)$ day $y^{-1}$, where $w_{i}$ and $w_{f}$ are the initial and 106 final mean wet body weight respectively. Oocyte development was monitored by biopsy.

107 Biopsies were carried out in all females of 1,3 and $8 \mathrm{~m}^{3}$ tanks and at 8 randomly chosen 108 females of the other experimental units $\left(16\right.$ and $\left.32 \mathrm{~m}^{3}\right)$. The diameter of the forty largest 109 oocytes was recorded. Plasma levels of steroid hormones, estradiol (E2), were monitored 110 during gametogenesis. E2 was quantified using a homologous enzyme-linked immunosorbent 111 assay (ELISA) based on the procedure described by Nash, Davail-Cuisset, Bhattacharyya, 112 Suter, Le Menn \& Kime (2000). Measurements of steroid levels were performed in the same 113 females as the determination of oocyte diameter.

114 During the spawning period, presence of spawn was checked every morning. The determination 115 of eggs viability was made at the "4 cells stage", using 3 samples of $15 \mathrm{ml}$ for each spawn. Eggs 
116 and oocytes were sorted according 3 criteria: live and considered as fertilized eggs (floating

117 eggs and visible cells), dead (sinking eggs) or not fertilized (floating eggs but invisible division of

118 cells). 3 samples by spawn were placed in cylindro-conical incubators of 1 liter in volume with a

119 renewal rate of $300 \%$ per hour. The water temperature was the same as in the spawning tanks.

120 Each day, the dead eggs were collected. At hatching, measurements on larvae were realized

121 under weak anaesthesia with ethylene glycol monophenylether. The following parameters were

122 evaluated:(1) Number of spawns by female, (2) fecundity; number of eggs by spawn and

123 relative fecundity; total number of eggs / weight of female, (3) viability rate (\%); $100 \times$ (number

124 of live eggs/total number eggs), (4) fertilization rate (\%); $100 \times$ (number of fertilized eggs/ total

125 number of eggs), (5) egg diameter ( $\mathrm{mm}$ ); evaluated on 40 eggs fertilized without apparent

126 abnormality in cells division. Values obtained for the spawns were means of 3 incubators. (6)

127 Length of larvae $(\mathrm{mm})$; mean total length of forty larvae alive and without skeletal

128 malformations. (7) Hatching rate (\%); $100 \times$ (number of larvae / number of eggs incubated). (8)

129 Malformation rate (\%): $100 \times$ (malformed larvae/larvae) and non-lethal malformation rate (\%):

$130100 \times$ (malformed alive larvae /larvae). A skeletal malformation is considered as non-lethal, if it

131 allows the survival of larvae.

132

133 Statistical analysis

134 All results are expressed as mean \pm SE. Data were compared using one-way ANOVA using

135 STATISTICA for Windows. Significant ANOVAs were followed by a post hoc multiple

136 comparison test (Newman-Keuls). Differences were considered to be significant at $\mathrm{P}<0.05$.

137 Before ANOVA analysis, data expressed in \% were arc sinus square-root transformed.

\section{Results}

141 The minimal value of oxygen saturation observed in the $3 \mathrm{~m}^{3}$ tank during the conditioning period

142 (75.2\% air saturation) remains superior to the minimum required for the well-being of sea bass.

143 This deficit $(-13 \%)$ compared with the other conditions was measured for approximately 2 
144 months. During the spawning period, the oxygen saturation rate remained above the minimum

145 required for the well being of fish (> $=79 \%)$.

146

147 Conditioning period

148 Temperature ranged from $9.1^{\circ} \mathrm{C}$ (8th December) to $20.1^{\circ} \mathrm{C}$ (27th August) for all tanks. From

149 March to August, the specific growth rate (SGR $\left(\%\right.$ day $\left.{ }^{-1}\right)$ in the $1 \mathrm{~m}^{3}$ tank was significantly lower

$150(0.07 \pm 0.02, P<0.05)$ than in other tanks $\left(3,8,16\right.$ and $\left.32 \mathrm{~m}^{3}\right)$ with a SGR equal to $0.17 \pm 0.01$,

$1510.14 \pm 0.01,0.17 \pm 0.01,0.18 \pm 0.01$ respectively. Although after August this difference

152 disappeared, the Specific Growth Rate of fishes from this condition remained significantly lower

$153\left(0.11 \pm 0.01 \%\right.$ day $\left.^{-1}\right)(P<0.05)$ than the fishes of other tanks, $0.2 \pm 0.01,0.16 \pm 0.01,0.19 \pm$

$1540.01,0.19 \pm 0.01 \%$ day $^{-1}$ for respectively 3,816 and $32 \mathrm{~m}^{3}$ tanks, for the whole conditioning 155 period. This is illustrated by the evolution of weight of fishes in the different conditions during the 156 conditioning period (Fig 1).

157 At the end of August, the mean oocytes diameter of females from 16 and $32 \mathrm{~m}^{3}$ were 158 significantly larger than for the females of 1,3 and $8 \mathrm{~m}^{3}$ tanks (Fig 2). This difference 159 disappeared progressively and at the end of the conditioning period, no significant difference 160 persisted (Table 1 and Fig 2).

161 Whatever the sampling date considered, the comparison of the mean concentration of E2,

162 connected with volume, does not show any significant difference; for example the E2 163 concentration at the end of conditioning period $\left(\mathrm{ng} \cdot \mathrm{ml}^{-1}\right)$ was $0.57 \pm 0.2,1.79 \pm 0.14,1.05 \pm$

$1640.33,1.27 \pm 0.15,1.06 \pm 0.18$ for respectively $1,3,8,16$ and $32 \mathrm{~m}^{3}$. The mean plasma concentration E2 of all females shows a significant peak in early October (Fig 3).

Figure 1166

Figure 2167

Figure 3168

169

170 Spawning period

171 During this period, the temperatures ranged from 9.4 to $13.5^{\circ} \mathrm{C}$. Fishes were transferred in the 172 spawning units on 20th December. The first spawn occurred on 7th February and the last one 
173 on 9th April. For the twice-spawning females, the spawning period lasted between 17 and 27

174 days (Table I). The lowest fecundity per spawn was observed for the three females $\left(n^{\circ} 2,5\right.$ and

175 15) conditioned in $1 \mathrm{~m}^{3}$, which showed the lowest total fecundity with only a spawn. The best 176 spawn fecundity and total fecundity were observed for two-spawning females ( $n^{\circ} 11$ and 14 ).

177 After statistical analysis, no relation was identified between rank of the spawn and the fecundity,

178 for the twice-spawning females.

179 The eggs viability rate was included between 50 and $98.2 \%$, except for a spawn with a nil 180 viability rate (female $n^{\circ} 8$ ). 7 of 13 spawns showed a viability rate superior to $80 \%$. No relation 181 was identified between conditioning volume and viability rate and between rank of spawn and 182 viability rate.

183 All fertilization rates were superior to $98 \%$ except for the first spawn of a female from $16 \mathrm{~m}^{3}$ 184 (86\%). The mean eggs diameter of all spawns varied from 1,15 $\pm 0.005 \mathrm{~mm}$ (the first spawn of a 185 female from $16 \mathrm{~m}^{3}$ ) to $1,24 \pm 0.004 \mathrm{~mm}$ (the first spawn of a female from $32 \mathrm{~m}^{3}$ ). This spawn 186 had a mean egg diameter that differed significantly $(P<0.05)$ from the other diameters of eggs.

187 There is no relation between the eggs diameter and fecundity rate or the weight of the female.

188 The hatching rates varied from $22 \%$ to $92 \%$ without relation between this parameter and the 189 volume of conditioning, spawn rank or viability rate.

190 Hatchings have started from 4 to 6 days after the beginning of the incubation and have 191 happened during one or two days. No difference was showed between the spawns. The 192 malformations rates have moved between 5.3\% (female from $8 \mathrm{~m}^{3}$ ) and $30 \%$ (female from 32 $193 \mathrm{~m}^{3}$ ), except the first spawn of the second female from $8 \mathrm{~m}^{3}$ with a malformations rate 194 significantly different (62\%). The non-lethal malformations represented 13 to $95 \%$ of the total 195 malformations. There was no relation between malformation rate and the conditioning volume.

197 The smallest larva measures $3.30 \mathrm{~mm}$, the greatest: $4.7 \mathrm{~mm}$. The smallest mean length is 3.66 $198 \pm 0.03 \mathrm{~mm}$ (second spawn of female 3 ) and the greatest is $4.28 \pm 0.03 \mathrm{~mm}$ (second spawn of 199 female 14), without significant difference between spawns. At the end of the experiment, the ovarian samples of females showed atretic oocytes. The mean weight loss of the females during the spawning period has been upper to males (respectively $20,8 \pm 1,56 \%$ et $14,6 \pm$ 
$2020,89 \%)$. Furthermore, the spawning females and those, which did not spawn, showed a weight

203 loss of $25.6 \pm 1,25 \%$ and $15,3 \pm 0,75 \%$, respectively.

204

\section{Discussion}

206 The growth observed for all experimental tanks is very weak during the first two months of the 207 experiment, with some conditions showing a loss of weight $\left(1\right.$ and $\left.8 \mathrm{~m}^{3}\right)$. In the second part of 208 the conditioning period all tanks have similar growth rates.

209 In addition, the evolution of oocyte diameter shows a significant difference between the smallest

210 volumes $\left(1,3\right.$ and $\left.8 \mathrm{~m}^{3}\right)$ and the largest, which disappears progressively; in November there is

211 no more difference. The differences of growth or kinetic of maturation observed in the first part

212 of the conditioning period are explained by a more difficult acclimatization phase for the fishes in

213 smallest volumes $\left(1,3\right.$ and $\left.8 \mathrm{~m}^{3}\right)$, during which a permanent static behavior of the fishes,

214 particularly, in $1 \mathrm{~m}^{3}$ tanks was observed whereas the other fishes take up rapidly all the

215 available space and show an active swimming behavior. A compensatory growth occurring after

216 a growth depression as described by Arendt (1997) or by Ali, Nicieza and Wootton (2003) could

217 explain this tightening.

218 The peak of plasma E2 concentrations observed in October corresponds with these obtained 219 during previous studies held on sea bass. (Mananos et al. 1997; Prat, Zanuy, Bromage \& 220 Carrillo 1999; Asturiano, Sorbera, Ramos, Kime, Carrillo \& Zanuy 2000). In the study of 221 Asturiano et al. (2000), this rise appears when oocyte mean diameter reach 650-700 $\mu \mathrm{m}$, 222 whereas in our study the oocyte diameter reached $400 \mu \mathrm{m}$. Moreover, previous study showed 223 the appearance of the E2 peak one or two months before spawn (Mananos et al. 1997; Prat et 224 al. 1999) or during the spawning period (Prat, Zanuy, Carrillo, De Mones \& Fostier 1990); our 225 study shows a peak earlier, four months before spawning period. These high levels of E2 are 226 useful for the preservation of the oocytes viability until the environmental conditions allow the 227 final maturation of oocytes. In our experimental conditions, the fall of the water temperature 228 (under $12^{\circ} \mathrm{C}$ from November) could explain the delay in the beginning of the spawning period 229 and the lapse of four months between the peak of E2 and the beginning of spawns. 
230 Our study showed that it is possible to obtain spontaneous spawns in small volumes $\left(2 \mathrm{~m}^{3}\right)$ in

231 contradiction with Fornies et al. (2001). The results obtained for the relative fecundity (mean of 232232000 eggs kg_1) are in agreement with Mananos et al. (1997), who calculated a value of 233293000 eggs kg_1. Because at least one female from each conditioning volume has 234 spontaneously spawned, we can conclude that none of the volumes tested blocks the 235 reproduction in the range studied. The low number of spawns obtained and the variability in 236 spawn results does not allow to show a gradual effect of the conditioning volume. One female 237 from the $3 \mathrm{~m}^{3}$ tank and two females from the $8 \mathrm{~m}^{3}$ tank had spawned twice and the total 238 fecundities associated are among the four best ones. All the females conditioned in $16 \mathrm{~m}^{3}$ have 239 spawned, but their fecundities are lesser. Only one female fromthe $1 \mathrm{~m}^{3}$ tank and one from the $24032 \mathrm{~m}^{3}$ tank had spawned and their fertilities were among the worst ones. The poor results 241 observed for the females from the $32 \mathrm{~m}^{3}$ tank can be explained by the stress induced by the 242 transfer from a large conditioning volume $\left(32 \mathrm{~m}^{3}\right)$ to a small spawning volume $\left(2 \mathrm{~m}^{3}\right)$ according to 243 Mugnier, Fostier, Guezou, Gaignon and Quemener (1998) who showed that turbots (S. 244 maximus) acclimatized in the smallest volume are more tolerant than those conditioned in a 245 large volume. Thanks to the good environmental conditions (especially the water temperature) 246 maintained during our study in contrast with the conditions of natural medium, the spawns 247 started in the first days of February, earlier than observed in the natural environment by 248 Boulineau-Coatanea (1969), who observed them during March-April. Bromage (1995) observed 249 the first spawn when females measured $35 \mathrm{~cm}$ and weighed1.5 kg, but the lack of spawn in 250 some tanks of our study does not seem to be related to fish length, because certain fish used in 251 our study spawned despite having dimensions lower than these limits. The variability observed 252 in the qualitative and quantitative characteristics of spawns induces us to conclude on the effect 253 of individual characteristics of the females that could conceal the possible effect of the volume.

254 No volume in the range studied had a blocking effect on the spawns, but from the results, 255 conditioning in the $8 \mathrm{~m}^{3}$ tank seems to be a minimal condition for the well-being and reproduction 256 of the sea bass.

257 This study will have to be supplemented by an analysis of the effect of the density, to seek for 258 the best compromise between the maximal number of available breeders and the minimal 
volume of stocking to use, in order to preserve the good performances of spawns and to improve the economic results of hatcheries.

264 Ali M., Nicieza A. \& Wootton R. J. (2003) Compensatory growth in fishes: a response to growth depression. Fish and Fisheries 4 (2), 147-190.

Ambali A.J.D. \& Little D.C. (1996) Studies on the effect of manipulating hapa size on broodstock conditioning of Oreochromis niloticus in fertilized earthen ponds. In: 3rd. Int. Symp. On Tilapia in Aquaculture, Abidjan (Côte d'Ivoire), 11-16 Nov 1991. (ed. by R.S.V. Pullin, J. Lazard, M. Legendre, J.B. Amon Kottias \& D. Pauly). ICLARM Conf. Proc., 41, 223-228.

Arendt J. D. (1997) Adaptive intrinsic growth rates: an integration across taxa. Quarterly Review of Biology 72, 149-177.

274

275 Asturiano J.F., Sorbera L.A., Ramos J., Kime D.E., Carrillo M. \& Zanuy S. (2000) Hormonal regulation of the European sea bass reproductive cycle: an individualized female approach. Journal of Fish Biology 56, 1155-1172.

278

279 Boulineau-Coatanea F. (1969) Contribution à l'étude biologique du bar Dicentrarchus labrax.

280 Thèse de $3^{\text {ème }}$ cycle, Faculté des Sciences, Univ. Paris. Océanographie et Biologie, 121p.

282 Bromage N.R. (1995) Broodstock management and seed quality-General considerations. In:

283 Broodstock management and egg and larval quality (ed. by N.R. Bromage \& R.J. Roberts), pp. 284 1-25, Blackwell Science, Oxford. 
286 Bromage N., Porter M. \& Randall C. (2001) The environmental regulation of maturation in 287 farmed finfish with special reference to the role of photoperiod and melatonin. Aquaculture 197, $288 \quad 63-98$.

289

290 Campbell PM., Pottinger TG. \& Sumpter JP. (1994) Preliminary evidence that chronic 291 confinement stress reduces the quality of gametes produced by brown and rainbow trout. 292 Aquaculture 120, 151-169.

294 Carrillo M., Zanuy S., Prat F., Cerda J., Ramos J., Mananos E. \& Bromage N. (1995) Sea bass 295 (Dicentrarchus labrax). In Broodstock management and egg and larval quality. (ed. by N.R. 296 Bromage \& R.J. Roberts), pp. 138-168, Blackwell Science, Oxford.

298 Cleary J.J., Pankhurst N.W. \& Battaglene S.C. (2000) The Effect of Capture and Handling 299 Stress on Plasma Steroid Levels and Gonadal Condition in Wild and Farmed Snapper Pagrus 300 auratus (Sparidae). Journal of world aquaculture society 31, 558-562.

301

302 Fornies M.A., Mananos E., Carrillo M., Rocha A., Laureau S., Mylonas C.C., Zohar Y. \& Zanuy 303 S. (2001) Spawning induction of individual European sea bass females (Dicentrarchus labrax) 304 using different GnRHa-delivery systems. Aquaculture 202, 221-234.

306 Goolish E.M., Evans R., Okutake K. \& Max R. (1998) Chamber volume requirements for 307 reproduction of the zebrafish Danio rerio. Progressive Fish Culturist 60, 127-132.

309 Mananos E.L., Zanuy S \& Carrillo M. (1997) Photoperiodic manipulations of the reproductive 310 cycle of sea bass (Dicentrarchus labrax) and their effects on gonadal development, and plasma

311 17beta-estradiol and vitellogenin levels. Fish Physiology and Biochemistry 16, 211-222.

313 Mugnier C., Fostier A., Guezou S., Gaignon JL. \& Quemener L. (1998) Effect of some repetitive 314 factors on turbot stress response. Aquaculture International 6, 33-45. 
316 Nash J.P., Davail-Cuisset B., Bhattacharyya S., Suter H.C., Le Menn F. \& Kime D.E. (2000) An

317 enzyme linked immunosorbant assay (ELISA) for testosterone, estradiol, and 17,20ß-dihydroxy-

318 4-pregenen-3-one using acetylcholinesterase as tracer: application to measurement of diel

319 patterns in rainbow trout (Oncorhynchus mykiss). Fish Physiology and Biochemistry 20, 355320363.

322 Okumura S., Okamoto K., Oomori R. \& Nakazono A. (2002) Spawning behavior and artificial 323 fertilization in captive reared red spotted grouper, Epinephelus akaara. Aquaculture 206, 165324173.

326 Prat F., Zanuy S., Carrillo M., De Mones A. \& Fostier A. (1990) Seasonal changes in plasma 327 levels of gonadal steroids of sea bass, Dicentrarchus labrax L. General and Comparative 328 Endocrinology 78, 361-373.

330 Prat F., Zanuy S., Bromage N. \& Carrillo M. (1999) Effects of constant short and long 331 photoperiod regimes on the spawning performance and sex steroid levels of female and male 332 sea bass. Journal of Fish Biology 54, 125-137.

334 Ridha M.T. \& Cruz E.M. (1999) Effect of different broodstock densities on the reproductive 335 performance of Nile tilapia, Oreochromis niloticus (L.), in a recycling system. Aquaculture 336 Research 30, 203-210.

338 Rodriguez L., Begtashi I., Zanuy S., Shaw M. \& Carrillo M. (2001) Changes in plasma levels of 339 reproductive hormones during the first sexual maturation in European male sea bass

340 (Dicentrarchus labrax L.) under artificial day lengths. Aquaculture 202, 235-248.

342 Schreck C.B., Contreras-Sanchez W. \& Fitzpatrick, M.S. (2001) Effects of stress on fish 343 reproduction, gamete quality, and progeny. Aquaculture 197, 3-24. 
345 Sehgal H.S. \& Toor H.S. (1995) Effect of stocking density on ovarian maturation, offspring

346 fitness and growth of common carp. Aquaculture 129, 113-117.

347

348 Siddiqui A.Q., Al-Harbi A.H. \& Hafedh Y.S. (1997) Effects of stocking density on patterns of 349 reproduction and growth of hybrid Tilapia in concrete tanks in Saudi Arabia. Asian Fisheries 350 Science 10, 41-49.

351

352 Suquet M., Normant Y., Gaignon J.L., Quéméner L. \& Fauvel C. (2005) Effect of water 353 temperature on individual reproductive activity of pollack (Pollachius pollachius). Aquaculture $354243,113-120$. 
Table I. Individual females characteristics at the end of vitellogenesis and individual females spawning characteristics. The values for oocyte diameter 356 correspond at mean \pm SE. Two numbers for the same female and the same parameter, corresponds to the values of two spawns. In a column, same 357 letter denotes homogeneous groups $(P>0.05)$.

\begin{tabular}{|c|c|c|c|c|c|c|c|c|c|c|c|}
\hline \multirow{2}{*}{ q } & \multirow{2}{*}{$\begin{array}{l}\text { Conditioning } \\
\text { volume }\left(\mathrm{m}^{3}\right)\end{array}$} & \multicolumn{4}{|c|}{ Data at the beginning of the spawning period (dec-15) } & \multirow{2}{*}{$\begin{array}{l}\text { Day of } \\
\text { spawn }\end{array}$} & \multirow{2}{*}{$\begin{array}{c}\text { Fecundity } \\
\left(\text { eggs.spawn }^{-1}\right)\end{array}$} & \multirow{2}{*}{$\begin{array}{c}\text { Relative } \\
\text { fecundity } \\
\left(\text { eggs. } \mathrm{kg}^{-1}\right)\end{array}$} & \multirow{2}{*}{$\begin{array}{l}\text { Viability } \\
\text { rate (\%) }\end{array}$} & \multirow{2}{*}{$\begin{array}{l}\text { Hatching } \\
\text { rate (\%) }\end{array}$} & \multirow{2}{*}{$\begin{array}{c}\text { Larval } \\
\text { deformity } \\
\text { rate (\%) }\end{array}$} \\
\hline & & Weight $(\mathrm{g})$ & $\begin{array}{c}\text { SGR } \\
\left(\% \text { day }^{-1}\right)\end{array}$ & $\begin{array}{l}\text { Estradiol } \\
\left(\mathrm{ng} \mathrm{ml}^{-1}\right)\end{array}$ & $\begin{array}{l}\text { Oocyte diameter } \\
\qquad(\mu \mathrm{m})\end{array}$ & & & & & & \\
\hline 1 & 8 & 1177 & 0.191 & 0.433 & $795.3 \pm 12.3$ & - & - & - & - & - & - \\
\hline 2 & 1 & 1256 & 0.108 & 0.958 & $770.7 \pm 12.6$ & - & - & - & - & - & - \\
\hline \multirow[t]{2}{*}{3} & \multirow[t]{2}{*}{16} & \multirow[t]{2}{*}{1562} & \multirow[t]{2}{*}{0.234} & \multirow[t]{2}{*}{0.847} & \multirow[t]{2}{*}{$790.0 \pm 11.7$} & $03 / 03$ & 173450 & \multirow{2}{*}{309456} & 52.0 & 38.3 & $13.5 \mathbf{a}$ \\
\hline & & & & & & $03 / 23$ & 309920 & & 88.7 & 75.8 & $17.6 \mathbf{a}$ \\
\hline 4 & 3 & 1291 & 0.209 & 2.057 & $816.0 \pm 10.1$ & - & - & - & - & - & - \\
\hline 5 & 1 & 936 & 0.033 & 0.315 & $693.3 \pm 18.0$ & - & - & - & - & - & - \\
\hline 6 & 32 & 940 & 0.173 & 1.484 & $797.3 \pm 6.3$ & $03 / 03$ & 95640 & 101745 & 98.2 & 92.3 & $29.6 \mathbf{a}$ \\
\hline \multirow[t]{2}{*}{7} & \multirow[t]{2}{*}{16} & \multirow[t]{2}{*}{1583} & \multirow[t]{2}{*}{0.213} & \multirow[t]{2}{*}{1.687} & \multirow[t]{2}{*}{$830.0 \pm 11.9$} & $02 / 12$ & 288980 & \multirow{2}{*}{215351} & 83.5 & 89.8 & $11.6 \mathbf{a}$ \\
\hline & & & & & & 03/09 & 51920 & & 83.5 & 45.0 & $16.3 a$ \\
\hline 8 & 16 & 1656 & 0.178 & 1.123 & $788.0 \pm 10.3$ & $04 / 06$ & 133930 & 80876 & 0.0 & - & - \\
\hline 9 & 3 & 1674 & 0.158 & 1.599 & $714.7 \pm 9.3$ & - & - & - & - & - & - \\
\hline 10 & 32 & 919 & 0.315 & 0.477 & $825.3 \pm 9.7$ & - & - & - & - & - & - \\
\hline \multirow[t]{2}{*}{11} & \multirow[t]{2}{*}{8} & \multirow[t]{2}{*}{1680} & \multirow[t]{2}{*}{0.187} & \multirow[t]{2}{*}{0.928} & \multirow[t]{2}{*}{$835.3 \pm 12.1$} & $02 / 07$ & 414690 & \multirow{2}{*}{469946} & 77.6 & 76.8 & $13.6 \mathbf{a}$ \\
\hline & & & & & & 03/05 & 374820 & & 72.9 & 78.3 & $5.3 a$ \\
\hline 12 & 32 & 1465 & 0.238 & 0.696 & $828.0 \pm 8.9$ & - & - & - & - & - & - \\
\hline \multirow[t]{2}{*}{13} & \multirow[t]{2}{*}{8} & 1400 & 0.223 & 0.467 & $848.0 \pm 12.4$ & $03 / 23$ & 207610 & 276257 & 64.7 & 31.3 & $62.0 \mathrm{~b}$ \\
\hline & & & & & & $04 / 09$ & 179150 & 276257 & 80.1 & 51.6 & $19.7 \mathbf{a}$ \\
\hline 14 & 3 & 2237 & 0.182 & 1.715 & $666.0 \pm 8.1$ & $03 / 03$ & 387260 & 379865 & 88.9 & 68.3 & $8.3 \mathbf{a}$ \\
\hline & & & & & & $03 / 30$ & 462500 & 379865 & 94.5 & 70.7 & $19.7 \mathbf{a}$ \\
\hline 15 & 1 & 1469 & 0.140 & 0.450 & $660.0 \pm 9.3$ & $03 / 07$ & 35240 & 23989 & 63.6 & 21.9 & $18.2 a$ \\
\hline
\end{tabular}




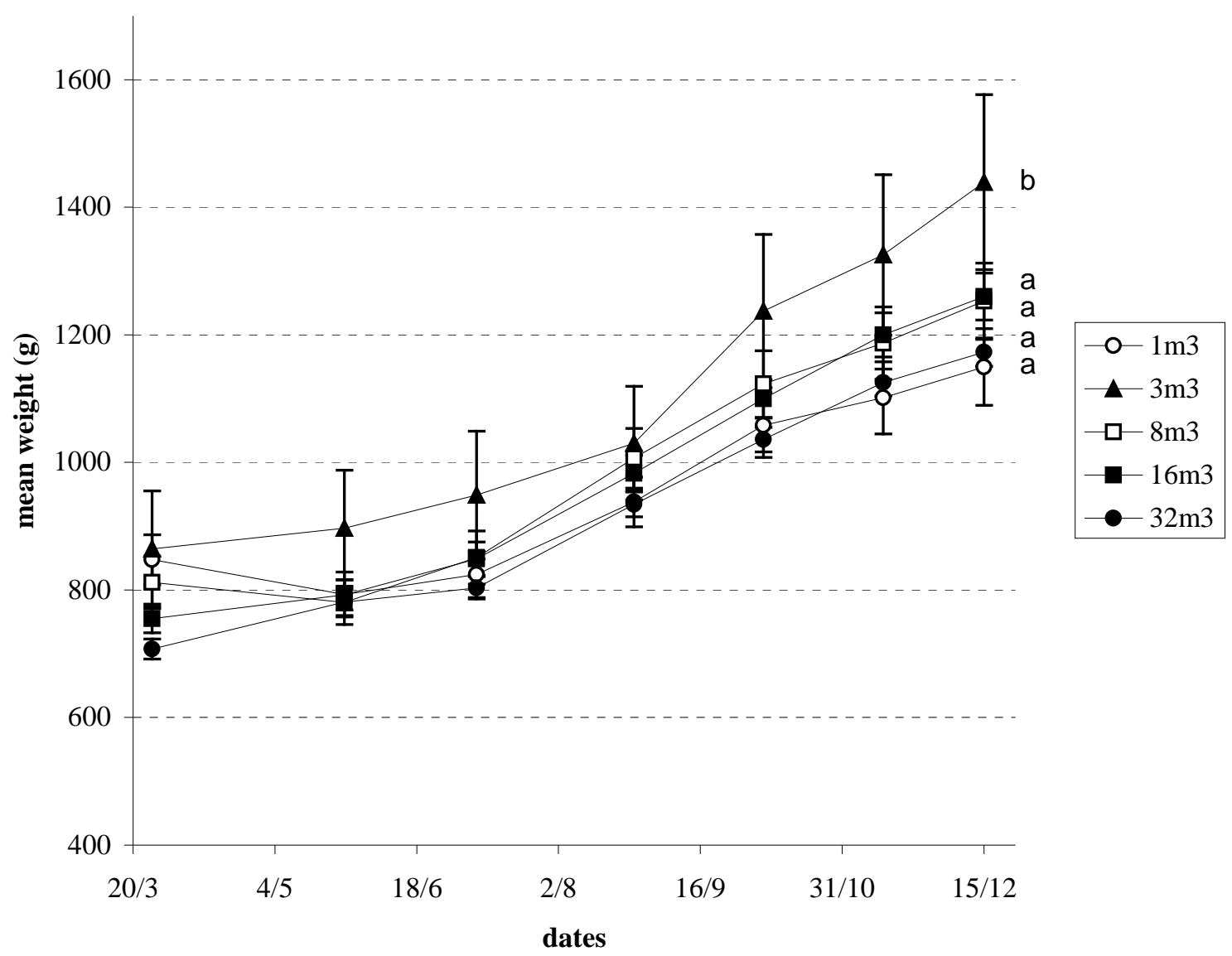

359 Figure 1: Change of mean weight over time in relation to the five conditioning volumes. Data are 360 given with SE (same letter denotes homogeneous groups $(P>0.05))$. ( $n=9$ for 1 and $3 m^{3}, n=24$, 36148,96 for respectively 8,16 and $32 \mathrm{~m}^{3}$ ) 


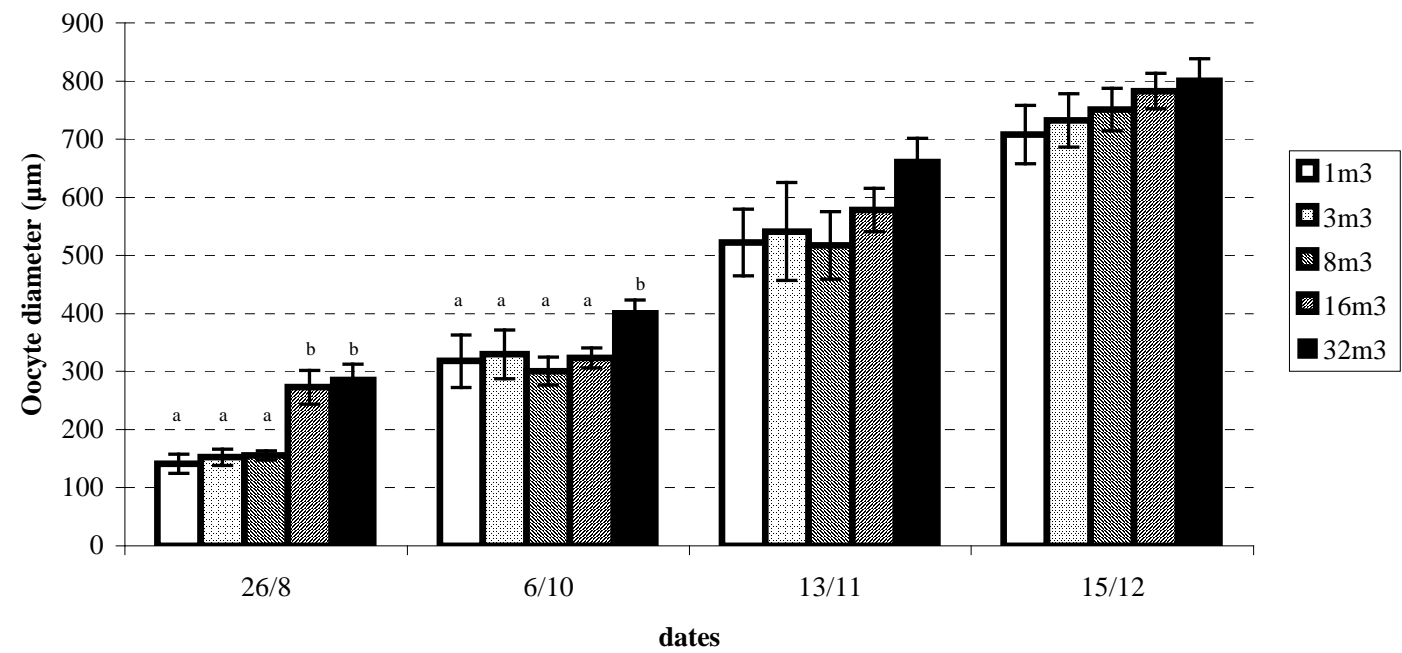

362 Figure 2: Changes of mean oocytes diameters over time in relation to the conditioning volume. 363 Data are given with SE (same letter denotes homogeneous groups $(P>0.05)$ ). $(n=3$ for 1 and $3643 \mathrm{~m}^{3}, \mathrm{n}=8$ for 8,16 and $32 \mathrm{~m}^{3}$ ) 


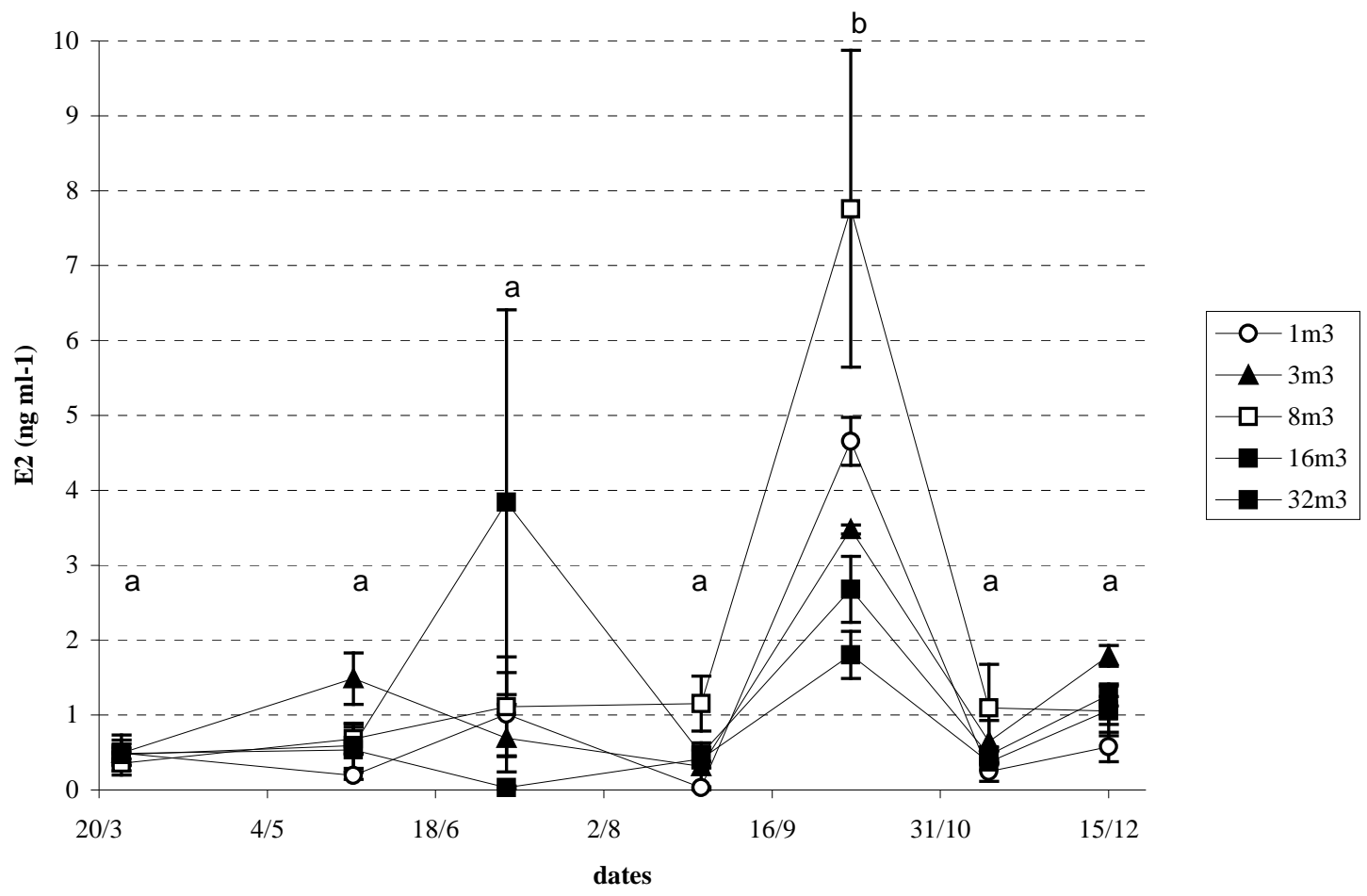

365 Figure 3: Evolution of plasma E2 concentrations over time in relation to conditioning volume. 366 Values are given with SE (measurement days not sharing a common letter have an average 367 plasmatic oestradiol concentration, for the whole of observed females, significantly different $368(P>0.05))$. $\left(n=3\right.$ for 1 and $3 m^{3}, n=8$ for 8,16 and $\left.32 m^{3}\right)$ 